\title{
A ground radiometric study of uranium, thorium and potassium in Isparta, Turkey
}

\author{
N. Ayten Uyanik ${ }^{1}$, İskender Akkurt ${ }^{2,{ }^{\star}}$, Osman Uyanik ${ }^{3}$ \\ ${ }^{1}$ Süleyman Demirel Üniversitesi, Deprem ve Jeoteknik Araştirma Merkezi, Isparta, Turkey \\ ${ }^{2}$ Süleyman Demirel Üniversitesi, Fen Edebiyat Fakültesi, Fizik Bölümü, Isparta, Turkey \\ ${ }^{3}$ Süleyman Demirel Üniversitesi, Müh-Mim. Fak., Jeofizik Müh. Bölümü, Isparta, Turkey
}

\section{Article history}

Received May 17, 2010; accepted October 12, 2010.

Subject classification:

Isparta volcanics, Gamma-ray spectrometry, Potassium, Uranium, Thorium.

\section{ABSTRACT}

The radioelement concentrations of uranium $\left({ }^{238} \mathrm{U}\right)$, thorium $\left({ }^{232} \mathrm{Th}\right)$ and potassium $\left({ }^{40} \mathrm{~K}\right)$, as their radionuclides $e U$, eTh and $K$, of Cünür Hill in the city of Isparta (Turkey) and its surroundings were measured using gamma-ray spectrometry with a $\mathrm{NaI}(\mathrm{Tl})$ detector. The measurements were performed over an area of $2 \mathrm{~km} \times 8 \mathrm{~km}$ around Cünür Hill, which forms part of the Isparta volcanic region that has a trachyandesitic composition, and which included the limestone outcrops east of Cünür. The results are mapped as combined radioelement concentrations. The radioelement concentrations of $e U, e T h$ and $K$ measured for Cünür Hill are high because of its trachyandesitic composition, while those measured in the limestone area were low, as would be expected.

\section{Introduction}

Natural radioactivity has existed since the universe began, and it has survived to date due to the long half-lives of various radioactive element series. These elements are mainly uranium $\left({ }^{238} \mathrm{U}\right)$, thorium $\left({ }^{232} \mathrm{Th}\right)$, and potassium $\left({ }^{40} \mathrm{~K}\right)$. Radiometric methods are one of the most powerful and rapid methods to obtain information about the distributions and concentrations of these radionuclides $(e U, e T h, K)$ in any specific areas. Moreover, using these methods, it is also possible to carry out geological and geochemical mapping [Durrance 1986, Aydin et al. 2006, Uyanık and Akkurt 2010].

The region around the city of Isparta (Turkey) is an interesting area, where many different tectonic structures are found. This region is rich in trachyandesitic rock and has large limestone exposures [Görmüş and Özkul 1995, Kanbur et al. 2008]. Several geological studies have been performed on this region [Gutnic et al. 1979, Görmüş and Özkul 1995, Yagmurlu et al. 1997, Koçyigit and Deveci 2007, Plateovet et al. 2008, Kanbur et al. 2008]. However, no complete studies for the regional radiometric data on this area are presently available, although there has been a report of measurements of the natural background radiation [Akkurt 2004].

In the present pilot study, the concentrations of the $e U$ and $e T h$ element series and $K$ activities around the Cünür Hill area of Isparta were measured using gamma-ray spectrometry with a $\mathrm{NaI}(\mathrm{Tl})$ scintillation detector. Annual effective outdoor doses were also estimated.

\section{Materials and methods}

\subsection{Geological setting}

The field measurements were performed at 60 locations on Cünür Hill and in the surrounding area near Isparta. The city of Isparta is located between the latitudes of $37^{\circ} 18^{\prime} \mathrm{N}$ and $38^{\circ} 30^{\prime} \mathrm{N}$. The height of Cünür Hill reaches about 1,090 $\mathrm{m}$, and its geological exposure consists mainly of volcanic sand, limestone and alluvium [Görmüş and Özkul 1995, Yagmurlu et al. 1997, Nemec and Kazanc1 1999, Görmüş et al. 2001, Francalanci et al. 2001].

This Isparta volcanic belongs to the post-collisional alkali potassic-ultrapotassic magmatism that has been active since the Miocene [Plateovet et al. 2008]. Figure 1 shows the location of Isparta within Turkey, and also the geological structure of Cünür Hill, near Isparta. The satellite view of the locations where the measurements were performed in the present study are shown in Figure 2.

\subsection{Activity measurements}

A portable GF Instruments (Isparta,Turkey) $\gamma$-ray spectrometer was used to measure the $e U$ (ppm), eTh (ppm) and $K(\%)$ elemental concentrations. The spectrometer consisted of a $\mathrm{NaI}(\mathrm{Tl})$ scintillation detector connected to a 512-channel pulse-height analyzer. The detector size was ca. $5 \mathrm{~cm} \times 5 \mathrm{~cm}$ and it was enclosed in a single integral unit with a photomultiplier tube, a high-voltage supply and a signal preamplifier. The calibration of the detector was carried out 


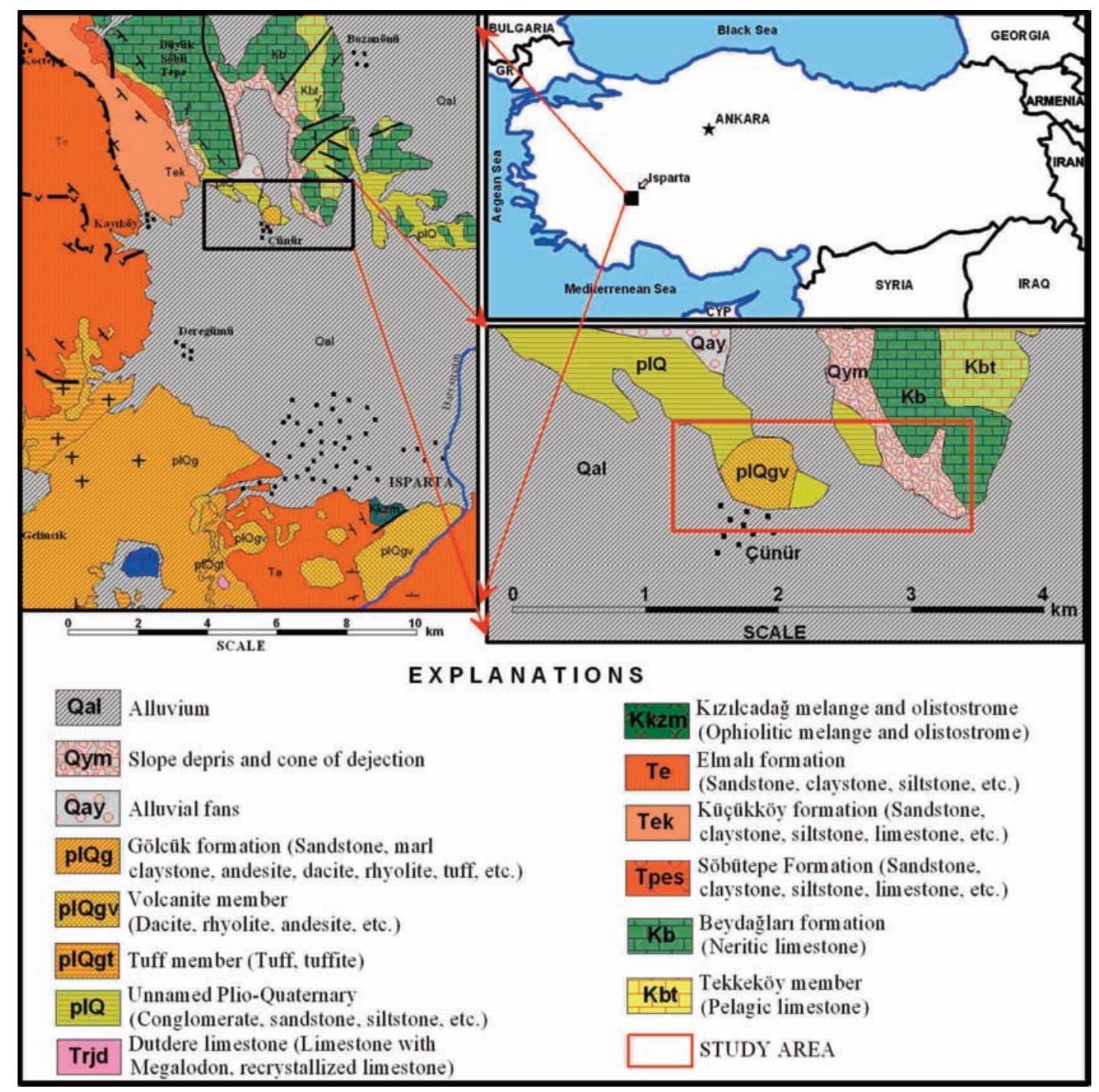

Figure 1. Geological map of Isparta [adapted from MTA 1997].

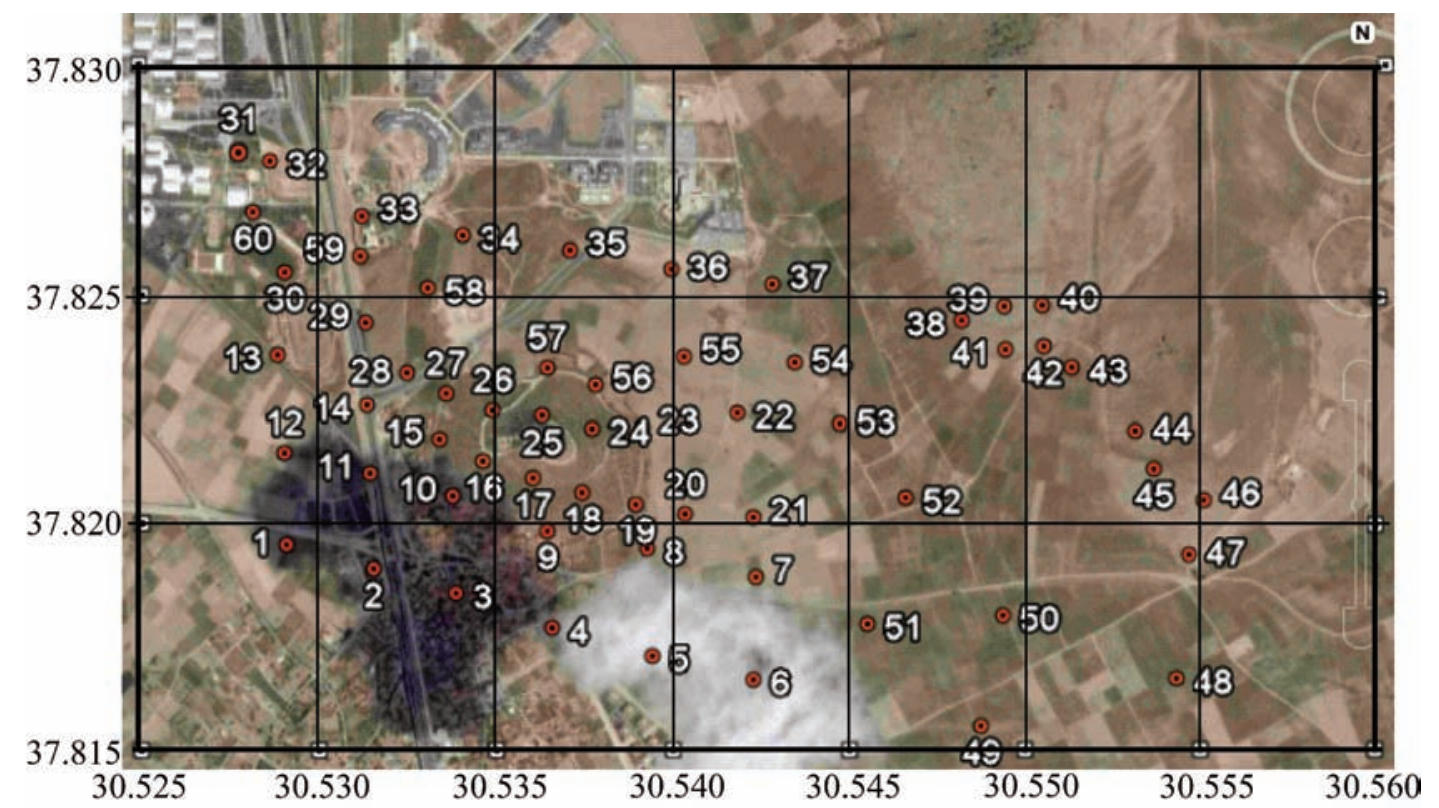

Figure 2. Satellite view of the study area and measurement locations. 


\begin{tabular}{|c|c|c|c|c|}
\hline Element & Nuclide & Half life & $\begin{array}{l}\text { Gamma-ray } \\
\text { energy }(\mathrm{keV})\end{array}$ & $\begin{array}{c}\text { Emission } \\
\text { rate }\end{array}$ \\
\hline \multirow{4}{*}{${ }^{238} \mathrm{U}$} & ${ }^{214} \mathrm{~Pb}$ & $26.8 \mathrm{~min}$ & 295.2 & 19 \\
\hline & & & 351.2 & 38.9 \\
\hline & ${ }^{214} \mathrm{Bi}$ & $19.9 \mathrm{~min}$ & 609.3 & 43.3 \\
\hline & & & 1764.7 & 17 \\
\hline \multirow{3}{*}{${ }^{232} \mathrm{Th}$} & ${ }^{208} \mathrm{Tl}$ & $3.05 \mathrm{~min}$ & 583.2 & 185.77 \\
\hline & & & 2614.7 & 99.79 \\
\hline & ${ }^{228} \mathrm{Ac}$ & $6.13 \mathrm{~h}$ & 911.1 & 22.7 \\
\hline${ }^{40} \mathrm{~K}$ & & $1.3 \times 10^{9} \mathrm{yr}$ & 1460.8 & 10.7 \\
\hline
\end{tabular}

Table 1. Natural radioactive elements analysed in this study.

\begin{tabular}{lccccc}
\hline Soil type & \multicolumn{6}{c}{ Elemental concentration } & Dose rate & AEDR \\
\cline { 2 - 4 } & $\begin{array}{l}\mathrm{eU} \\
(\mathrm{ppm})\end{array}$ & $\begin{array}{c}\mathrm{eTh} \\
(\mathrm{ppm})\end{array}$ & $\begin{array}{c}\mathrm{K} \\
(\mathbf{\%})\end{array}$ & $(\mathbf{n G y} / \mathbf{h})$ & $(\mathbf{m S v} / \mathbf{y})$ \\
\hline Alluvium & 10.3 & 25.8 & 1.94 & 148.2 & 0.18 \\
Trachyandesite & 11.2 & 39.3 & 2.31 & 191.9 & 0.23 \\
Limestone & 2.65 & 3.4 & 0.1 & 25.2 & 0.03 \\
\hline
\end{tabular}

Table 2. Elemental concentrations, absorbed gamma dose rates and the annual effective doses determined, according to the soil types in the study area.

using the ${ }^{137} \mathrm{Cs}$ isotopic source that is mounted inside the probe. The natural radioactivity measurements were based on recording the quantities of the three natural long-lived elements: $e U, e T h$ and $K$, based on their positioning at 1,760 $\mathrm{keV}, 2,610 \mathrm{keV}$ and $1,461 \mathrm{keV}$ respectively, in the energy spectrum. Table 1 gives the gamma-ray energies and emission rates for these nuclides [Baloguna et al. 2003]. Each of the measurements was performed at ca. $50 \mathrm{~cm}$ above the ground, for $5 \mathrm{~min}$.

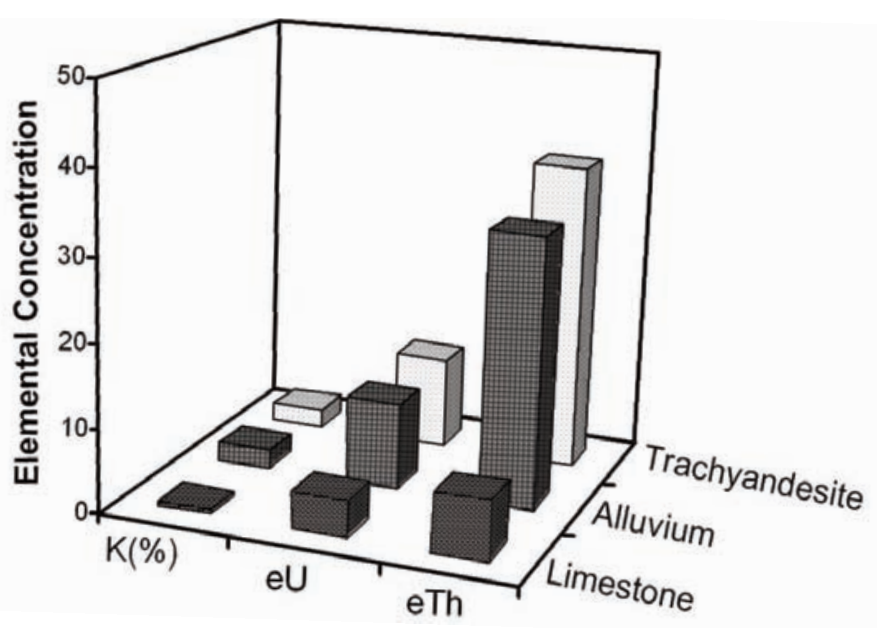

Figure 3. Elemental concentrations for the three types of soil.

\section{Results and discussions}

In-situ measurements were performed to obtain the mean elemental concentrations of $e U, e T h$ and $K$ for the different soil types in the Cünür Hill region. Overall, the results showed $13 \mathrm{ppm}, 40 \mathrm{ppm}$ and $2.4 \%$, for $e U$, $e T h$ and $K$, respectively. These data are given in Table 2 and illustrated in Figure 3, according to the alluvium deposits, and trachyandesitic and limestone soil types. As can be seen from Table 2 and Figure 3, the elemental concentrations vary across the different soil and rock types. The highest mean elemental concentrations were calculated from locations where there are trachyandesite outcrops, and the lowest mean concentrations were obtained from the limestone locations.

The overall absorbed gamma dose rates in air due to the combined activities of these $e U$ and $e T h$ element series and $K$ were also measured, using a GF Instruments survey meter. The data are shown in Table 2 according to the means within each soil type, and in Figure 4 for all of the individual locations, with the latter data ranging from $24.4 \mathrm{nGy} / \mathrm{h}$ to $218.4 \mathrm{nGy} / \mathrm{h}$. For the trachyandesitic rock, the relative contribution to the dose due to the $e T h$ element series is the greatest (73.5\%), followed by the $e U$ element series (21.9\%)

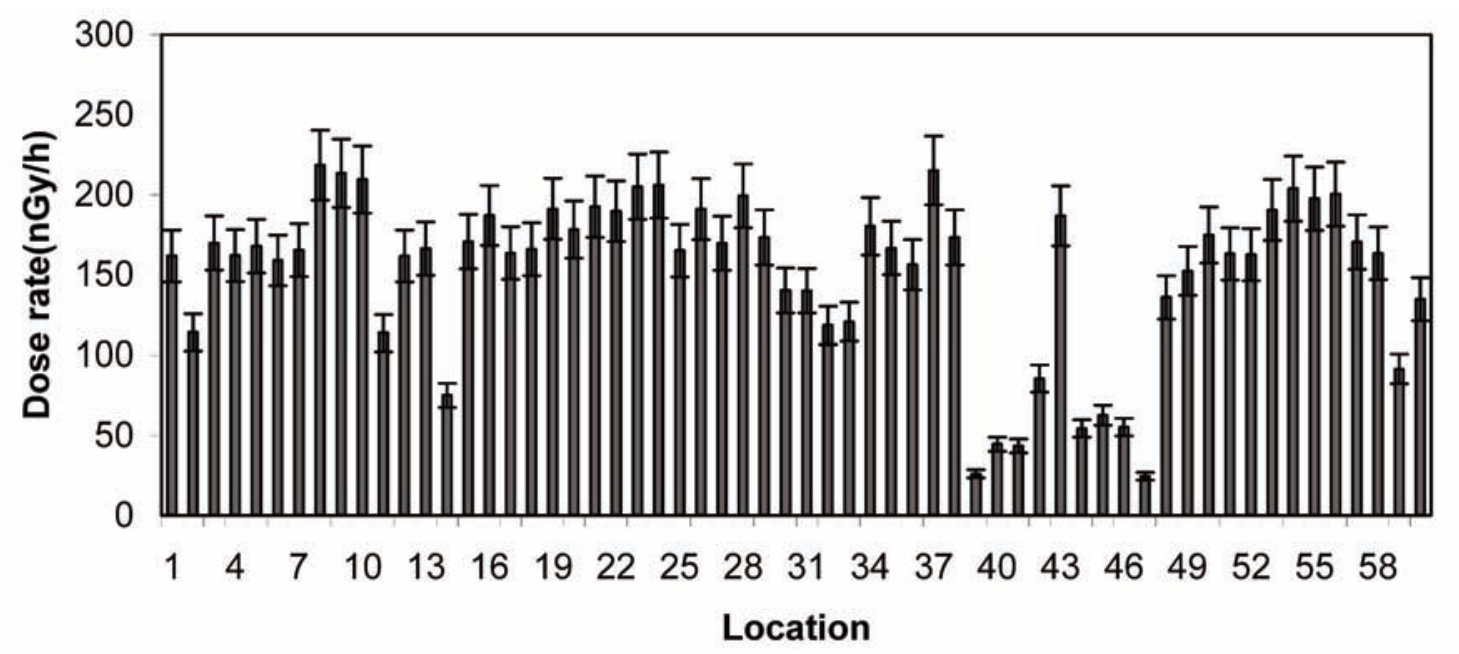

Figure 4. Absorbed dose rates across all of the sampling locations. 


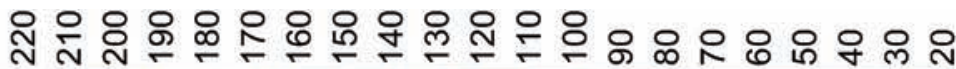

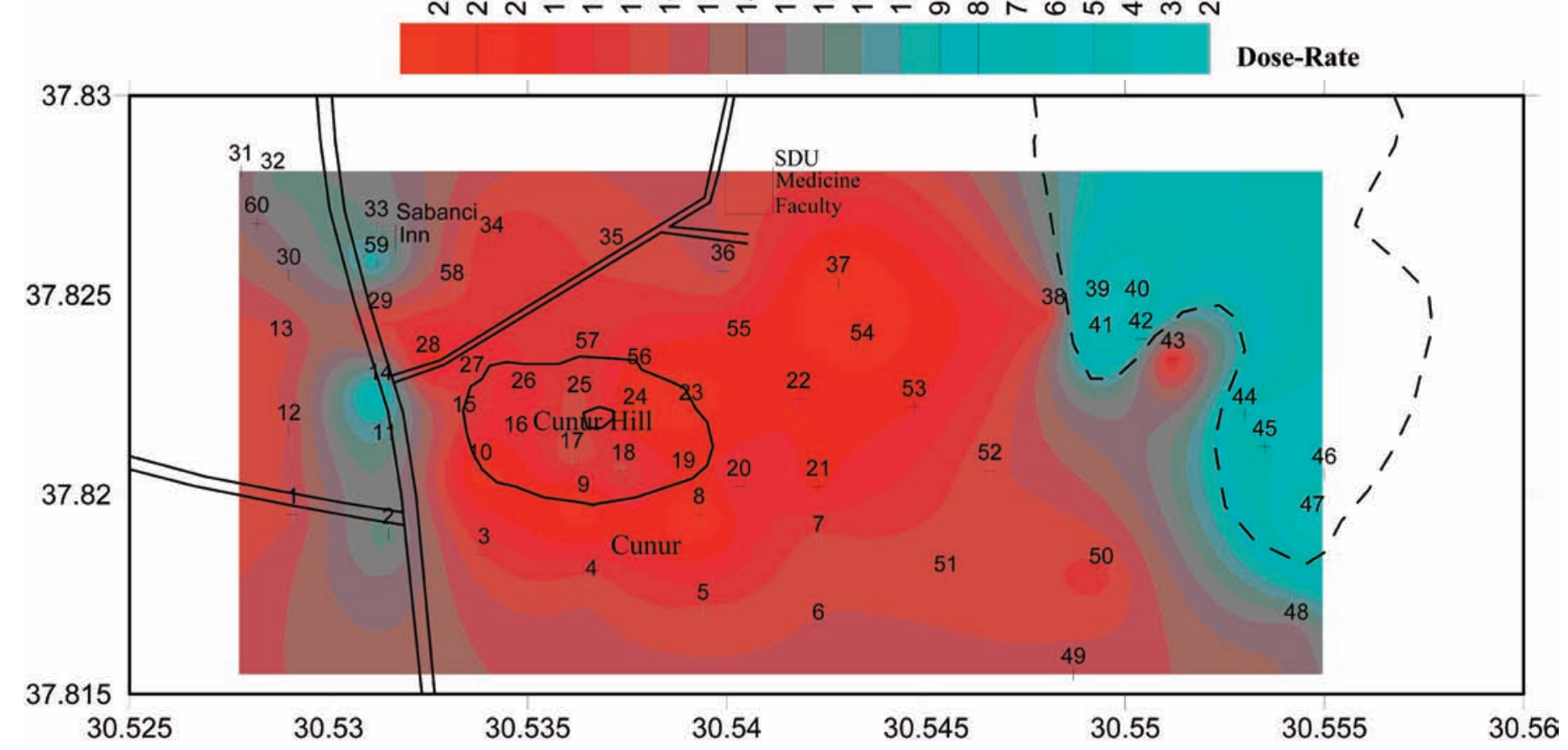

Figure 5. Absorbed dose rate distribution for Cünür Hill and its surroundings.

and $K(4.6 \%)$. For the alluvium, this is similar: $e T h$ with the greatest contribution for the gamma dose rate $(71.7 \%)$, followed by the $e U$ element series $(23 \%)$ and $K(4.3 \%)$. However, for the limestone, the relative contribution to the dose rate due to the $e T h$ element series is lower, at $59.1 \%$. The mapped combined gamma dose rate distribution according to the sample locations for Cünür Hill and the surrounding areas is shown in Figure 5. As can be seen from Figure 5 , the highest gamma dose rate is at location 8 , which is in the trachyandesite area, and the lowest is at location 47 , which is in the limestone field. The low values for these combined gamma dose rates are seen especially to the northeast of Cünür Hill, which again will be due to the large occurrence of limestone in this area.

This study area also includes trachyandesitic rock that forms the volcanic structure of Cünür Hill. It can be seen from Figure 4 and Figure 5 that the concentrations at the top of the hill are lower than those at other locations around the hill. This could be the result of the spreading of the trachyandesitic structure out of the hill, due to gravitation effects, and it might also due to meteorological effects on the soil characteristics. This could also be the result of using chemical materials on the cultivated land. The overall dose rate results classified according to the soil types on and around Cünür Hill are given in Table 2; as can also be seen from Figure 6, the soil that contains trachyandesite has higher dose rates than the other soil types.

The annual effective dose rate (AEDR) is an important parameter for the evaluation of radiation hazards due to the absorption from these dose rates. Using the conversion coefficient from the absorbed dose in air to the effective dose
$(0.7 \mathrm{~Sv} / \mathrm{Gy})$ and 0.2 for the outdoor occupancy factor, which indicates that on average, $20 \%$ of our time all around the World is spent outdoors [UNSCEAR 2000], the AEDR was obtained from the following formula [Cevik et al. 2007, Turhan et al. 2008]:

$\operatorname{AEDR}(\mathrm{mSv} / \mathrm{y})=$

$=\mathrm{D}(\mathrm{nGy} / \mathrm{h}) \times 8760(\mathrm{~h} / \mathrm{y}) \times 0.2 \times 0.7(\mathrm{~Sv} / \mathrm{Gy}) \times 10^{-6}$

The AEDR values obtained range between 0.03 and 0.74 $\mathrm{mSv} / \mathrm{y}$ across all of the sampling locations. These data were combined according to the three soil types on and around Cünür Hill, and these mean values are given in Table 2 and illustrated in Figure 7. As can be seen, the values obtained are under the recommended limits of $1 \mathrm{mSv} / \mathrm{y}$. These annual effective dose rates are also compared with the values obtained for other locations in other studies, as illustrated in Figure 8 [Orgun et al. 2005, Hafezi et al. 2005, Kilic and Aykamis 2009, Bozkurt et al. 2007]; as can be seen, all of these values are under the recommended limits.

\section{Conclusion}

It can be concluded from the present study that as well as measurements of elemental concentrations, this radiometric method can be used for the mapping of geological fields. This helps to illustrate sources of the rock minerals in terms of the radioactivity revealed. On the other hand all of the values obtained in this study remain under the recommended values. To determine the radioactivity levels of Isparta as a region in Turkey, this type of study can be further enlarged from the Cünür area. 


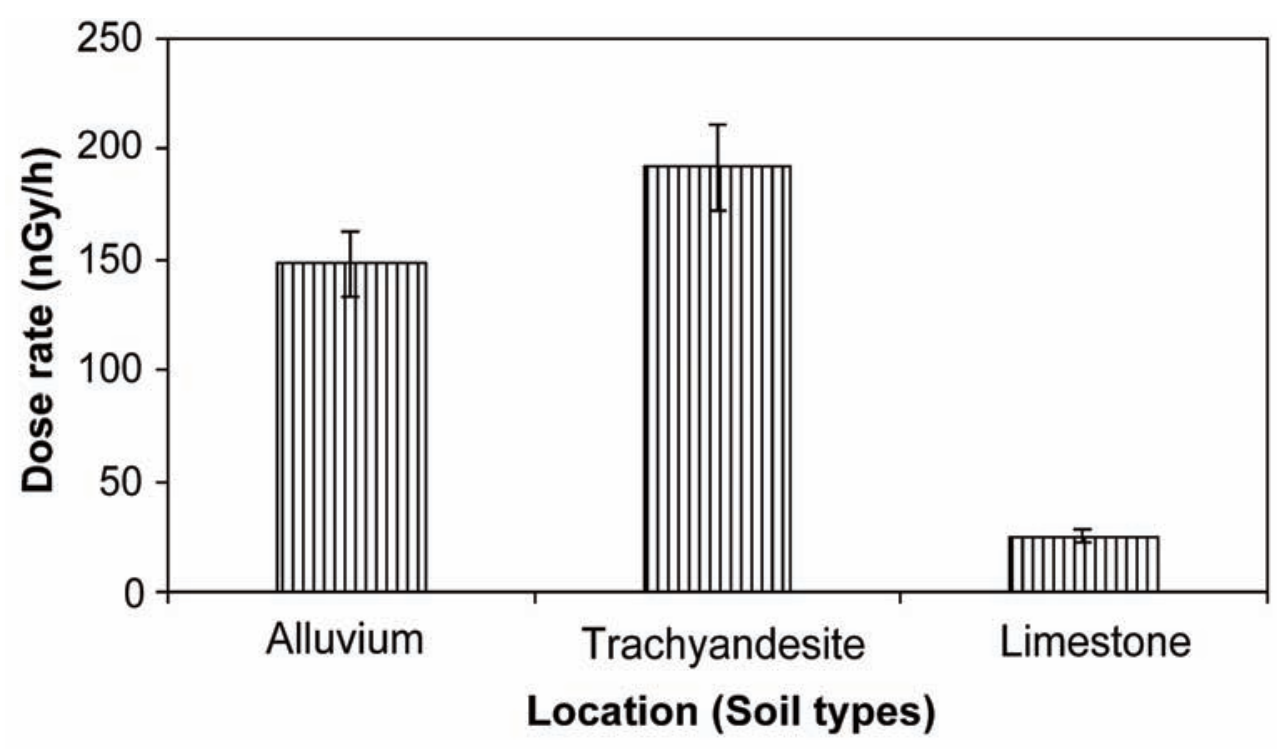

Figure 6. Absorbed dose rate classified according to soil type.

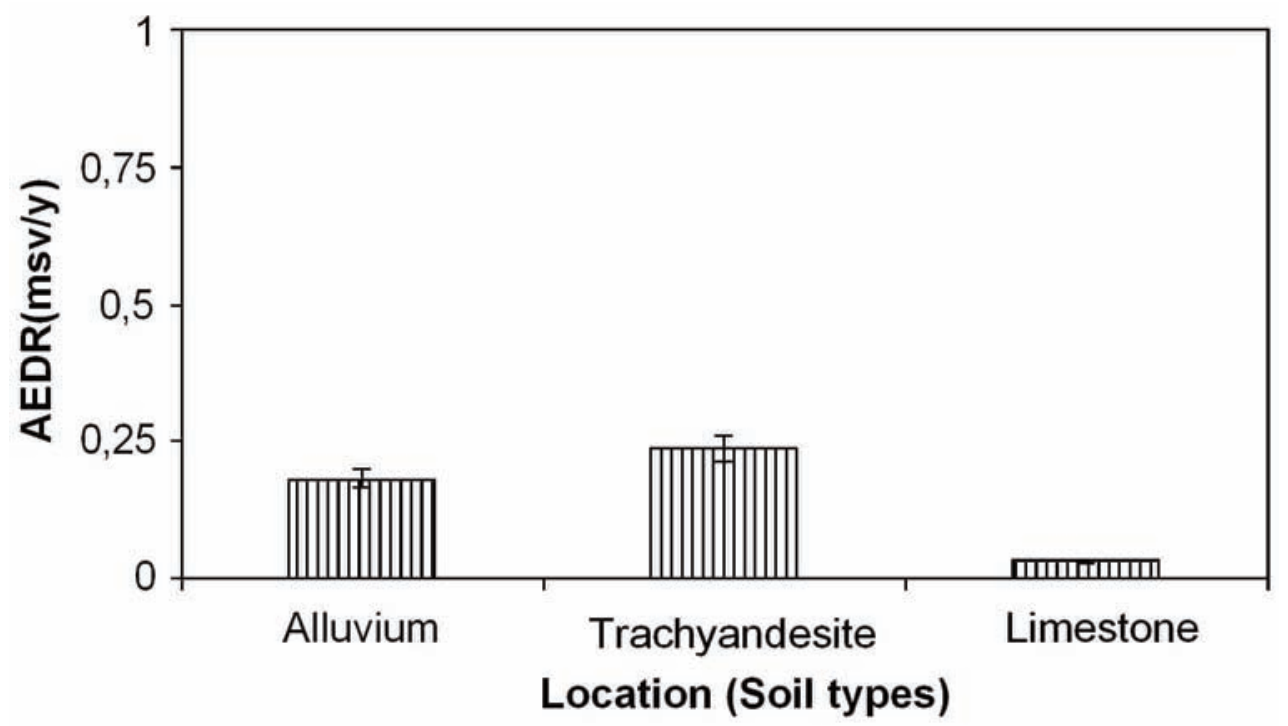

Figure 7. Effective dose rate as a function of the soil types around Cünür Hill.

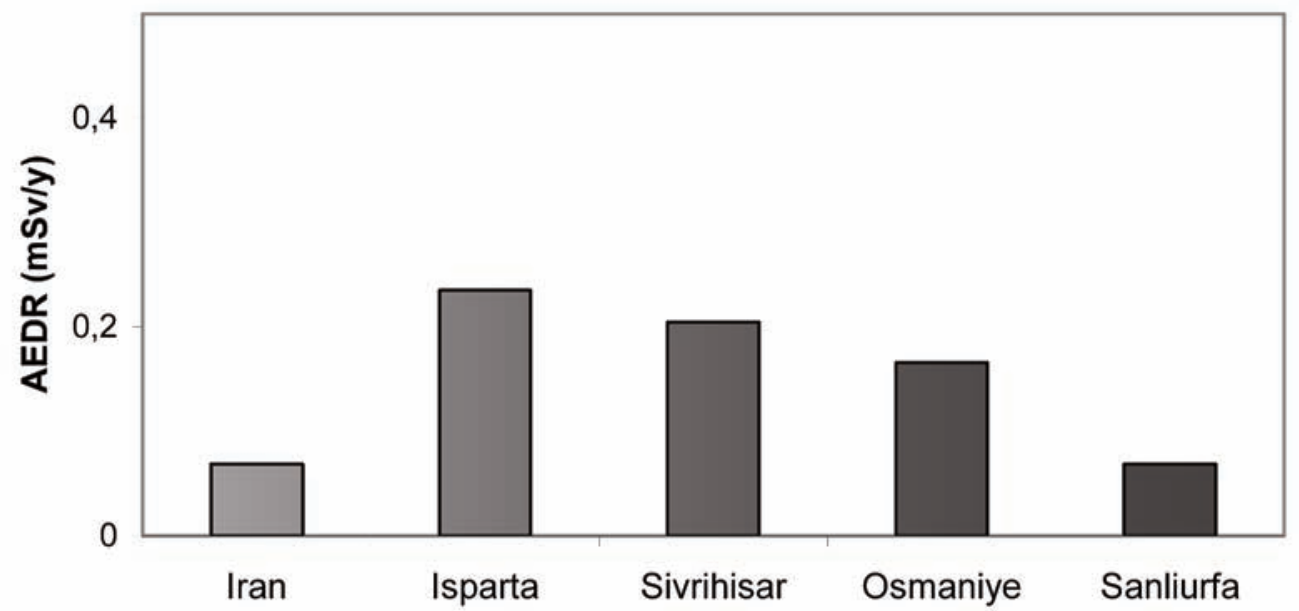

Figure 8. Effective dose rates for the trachyandesitic rock in the present study in comparison with other published measurements: Tehran, Iran [Hafezi et al. 2005], the city of Isparta (present study), the town of Sivrihisar [Orgun et al. 2005], the province of Osmaniye [Kilic and Aykamis 2009], and the region of Saliurfa [Bozkurt et al. 2007]. 
Acknowledgements. This study was supported by the Suleyman Demirel University Research Foundation Unit (1913 D 09).

\section{References}

Akkurt, V. D. (2004). Isparta ve Çevresinin Dogal gamma Radyasyonunun Ölçümü S.D.Ü. Fen Bil. Enstitüsü Dergisi 8-2, Special issue, 108.

Aydin, I., M.S. Aydogan, E. Oksum and A. Koçak (2006). An attempt to use aerial gamma-ray spectrometry results in petrochemical assessments of the volcanic and plutonic associations of Central Anatolia (Turkey), Geophys. J. Int., 167, 1044-1052.

Baloguna, F.A., C.E. Mokobia, M.K. Fasasia and F.O. Ogundare (2003). Natural radioactivity associated with bituminous coal mining in Nigeria, In: Proceedings of the tenth Symposium on Radiation Measurements and Applications, Nucl. Instrum. Meth. A., 505 (1-2), 444-448.

Bozkurt, A., N. Yorulmaz, E. Kam, G. Karahan and A. Erdal Osmanlioglu (2007). Assessment of environmental radioactivity for Sanliurfa region of southeastern Turkey, Radiat. Meas., 42 (8), 1387-1391.

Cevik, U., N. Damla and S. Nezir (2007). Radiological characterization of Cayırhan coal-fired power plant in Turkey, Fuel, 86 (16), 2509-2513.

Durrance, E.M., (1986). Radioactivity in Geology: Principles and Applications, Ellis Horwood Limited, Chichester, UK, 441 pp.

Francalanci, L., L. Civetta, F. Innocenti and P. Manetti (2001). Neogene alkaline volcanism of the Afyon-Isparta area, Turkey: Petrogenesis and geodynamic implications, Miner. Petrol., 70, 285-312.

Görmüş, M. and M. Özkul (1995). Gönen-Atabey (Isparta) ve Aglasun (Burdur) arasındaki bölgenin stratigrafisi. Süleyman Demirel Üniversitesi Fen Bilimleri Enstitüsü Dergisi, 1, 43-64.

Görmüş, M., S. Caran, H. Çoban and K. Yılmaz (2001). BedreBarla (Egirdir Gölü batısı) arasında kıyı kenar çizgisi. 1, Egirdir Sempozyumu, Isparta, 387-402.

Gutnic, M., O. Monod, A. Poisson and J.F. Dumont (1979). Géologie des Taurides Occidentales (Turquie), Mem. S. Geo. F., 137, 1-112.

Hafezi, S., J. Amidi and A. Attarilar (2005). Concentration of natural radionuclides in soil and assessment of external exposure to the public in Tehran, Iran, J. Radiat. Res., 3, 85-88.

Kanbur, Z., M. Görmüş and S. Kanbur (2008). Isparta yerleşim alanı kuzey kesiminin sıg S-Dalgası kesitinin çıkarılamsında Kırınım-Microtremor tekniginin (ReMi) kullanılması, Hacettepe Üniversitesi Yerbilimleri Dergisi, 29, 77-86.

Kilic, A.M. and A.S. Aykamis (2009). The natural radioactivity levels and radiation hazard of pumice from the east Mediterranean Region of Turkey, B. Eng. Geol. Environ., 68, 331-338.

Koçyigit, A. and S. Deveci (2007). A N-S trending active exten- sional structure the Suhut (Afyon) graben: Commencement age of the extensional neotectonic period in the Isparta Angle, SW Turkey, Turk. J. Earth Sci., 16, 391-416. MTA (1997). Maden Tetkik Arama Enst., 1997 Report.

Nemec, W. and N. Kazanc1 (1999). Quaternary colluvium in west-central Anatolia: sedimantary facies and palaeoclimatic significance, Sedimentology, 46, 139-170.

Orgun, Y., N. Altinsoy, A.H. Gültekin, G. Karahan and N. Celebi (2005). Natural radioactivity levels in granitic plutons and groundwaters in southeast part of Eskisehir, Turkey, Appl. Radiat. Isotopes, 63 (2), 267-275.

Platevoet, B., S. Scaillet, H. Guillou, D. Blamart, S. Nomade, M. Massault, A. Poisson, Ö. Elitok, N. Özgür, F. Yagmurlu and K. Y1lmaz (2008). Pleistocene eruptive chronology of the Gölcük Volcano, Isparta Angle, Turkey, Quaternaire, 19 (2), 147-156.

Turhan, S., U.N. Baykan and K. Sen (2008). Measurement of the natural radioactivity in building materials used in Ankara and assessment of external doses, J. Radiol. Prot., 28, 83-91.

UNSCEAR (2000). United Nations Scientific Committee on the Effects of Atomic Radiation. Sources, Effects and Risks of Ionizing Radiation, Report to the General Assembly with Annex B: Exposures from Natural Sources of Radiation, United Nations, New York.

Uyanık, N.A. and I. Akkurt (2010). Alkali volkanitler yönünden zengin olan Isparta-Çünür Tepesinde dogal radyoaktivite tayini. Afyon Kocatepe Üniversitesi, Fen Bilimleri Dergisi, Cilt 9, Say1 2.

Yagmurlu, F., Y. Savaşçın and M. Ergun (1997). Relation of alkaline volcanism and active tectonism within the evolution of the Isparta Angle, SW Turkey, J. Geol., 105 (6), 717-728.

${ }^{\star}$ Corresponding author: Iskender Akkurt,

Süleyman Demirel Üniversitesi, Fen Edebiyat Fakültesi, Fizik Bölümü, Isparta, Turkey; e-mail: iskender@fef.sdu.edu.tr.

C 2010 by the Istituto Nazionale di Geofisica e Vulcanologia. All rights reserved. 